\title{
STUDI KASUS TENTANG HUBUNGAN STATUS BIDAN PRAKTEK SWASTA DENGAN PELAYANAN ANTENATAL CARE DI WILAYAH PUSKESMAS BUMIJAWA KABUPATEN TEGAL TAHUN 2016
}

\author{
Baeti Rizki*Lilis Banowati**
}

\begin{abstract}
ABSTRAK
Banyak faktor yang mempengaruhi terpenuhinya cakupan $\mathrm{K} 4$, diantaranya kesadaran masyarakat tentang pentingnya pemeriksaan kehamilan serta kualitas tenaga kesehatan. Berdasarkan data dari Ikatan Bidan Indonesia cabang Kabupaten Tegal, bahwa jumlah bidan yang telah mempunyai izin praktik di wilayah Kabupaten Tegal adalah 513 bidan, sedangkan yang sudah bersertifikat sebagai bidan delima sebanyak 105 orang bidan. Tujuan penelitian untuk mengetahui hubungan status bidan praktek swasta dengan pelayanan antenatal care di wilayah puskesmas Bumijawa Kabupaten Tegal tahun 2016. Jenis penelitian adalah survei analitik, desain penelitian yang digunakan observasi dengan pendekatan cross sectional. Populasi dalam penelitian ini bidan yang membuka praktik mandiri di wilayah Puskesmas Bumijawa sejumlah 24 bidan. Teknik sampelnya menggunakan metode total sample yaitu 24 responden. Karakteristik bidan yang bekerja di wilayah Kecamatan Bumijawa Kabupaten Tegal bahwa rata-rata umur responden 36,29 tahun, sebagian besar responden berpendidikan D-III (91,7\%), sebagian besar lama mengabdi responden 5-10 tahun (54,2\%). Status bidan sebagian besar dengan status bidan praktek swasta bukan delima (58,3\%). Pelayanan Antenatal Care sebagian besar bermutu $(58,3 \%)$. Ada hubungan yang signifikan antara status bidan praktek swasta dengan pelayanan antenatal care di wilayah kecamatan Bumijawa Kabupaten Tegal tahun 2016 ( $\mathrm{X}^{2}$ hitung 5,531 dan $p$ value $\left.=0,024\right)$. Hal ini berarti bahwa bidan dengan status bidan delima lebih profesional dalam pelayanan ANC dibandingkan dengan bidan praktek swasta yang bukan delima, dengan menjadi bidan delima secara tidak langsung fasilitas pelayanan akan tersedia, sehingga akan meningkatkan mutu pelayanan.

Diharapkan bidan praktek swasta yang belum delima agar dapat mengikuti program bidan delima, sehingga dalam melakukan pelayanan ANC sesuai dengan standar pelayanan, serta dengan memasang famplet acuan pelayanan ANC sesuai dengan petunjuk dari Departemen Kesehatan.
\end{abstract}

Kata Kunci : Status bidan, antenatal care

\begin{abstract}
Many factors affect the fulfillment of K4 coverage, including public awareness about the importance of prenatal care and the quality of health workers. Based on data from the Indonesian Midwives Association branch Tegal regency, that the number of midwives who already have a license in the district of Tegal is 513 midwives, while that has been certified as a midwife pomegranate were 105 midwives. The aim of research to determine the relationship status private midwife with antenatal care in the health centers Bumijawa Tegal 2016.

This type of research is an analytical survey, design research used observational with cross sectional approach. The population in this study independent midwife who practices in the area at Puskesmas Bumijawa some 24 midwives. Mechanical sample using a method that is on the total sample of 24 respondents.

Characteristics of midwives who work in the District of Tegal Bumijawa that the average age of 36.29 years old respondents, the majority of respondents educated D-III (91.7\%), the majority of respondents serve 5-10 years old $(54.2 \%)$, Status midwives mostly with private midwife status instead of pomegranate (58.3\%). Antenatal Care qualified majority $(58.3 \%)$. There was a significant correlation between the status of private midwives with antenatal care in districts of Bumijawa Tegal 2016 (X2 count 5.531 and $\mathrm{p}$ value $=0.019$ ). This means that the midwife with midwife status pomegranate professionals in ANC compared with private midwife is not a pomegranate, with a midwife indirectly pomegranate service facilities will be available, so that will increase the quality of care.

Expected private midwives who have to follow our pomegranate midwife program, so that in conducting ANC in accordance with service standards, and by installing a reference pamphlet ANC in accordance with the instructions of the Ministry of Health.
\end{abstract}

Keywords : Status midwife, antenatal care

\footnotetext{
*Alumni PSKM STIKes Cirebon

**Staf Pengajar PSKM STIKes Cirebon
} 


\section{PENDAHULUAN}

Ikatan Bidan Indonesia (IBI), Badan Kesejahteraan Keluarga Berencana Nasional (BKKBN), dan Departemen Kesehatan (Depkes) pada 2004 dalam peningkatan kualitas Sumber Daya Manusia (SDM), meluncurkan program Bidan Delima (BD). Tujuan Program Bidan Delima berusaha untuk meningkatkan pelayanan yang berkualitas dengan cara melengkapi sarana dan prasarana serta memberikan pelayanan yang standar.

Ikatan Bidan Indonesia (IBI) terus berpacu untuk menjadikan bidan semakin professional. Karenanya, Ikatan Bidan Indonesia di Jawa Tengah mulai awal tahun 2005, meluncurkan bidan delima sebagai upaya nyata melahirkan bidan berkualitas dalam menyelamatkan kaum ibu hamil dan melahirkan dan anak yang dilahirkannya. ${ }^{1}$

Berdasarkan data dari Ikatan Bidan Indonesia cabang Kabupaten Tegal, bahwa jumlah bidan yang telah mempunyai izin praktik di wilayah Kabupaten Tegal adalah 513 bidan, sedangkan yang sudah bersertifikat sebagai bidan delima sebanyak 105 orang bidan. Bidan Praktek Swasta (BPS) merupakan Bidan yang memiliki Surat Ijin Praktek Bidan (SIPB) sesuai dengan persyaratan yang berlaku, dicatat (register) diberi izin secara sah dan legal untuk menjalankan praktek kebidanan mandiri, sedangkan pada program bidan delima adalah sebuah program yang diciptakan untuk para BPS dalam rangka meningkatkan dan pembinaan kualitas pelayanan KB dan Kesehatan reproduksi secara berkesinambungan dengan sertifikat bidan delima. ${ }^{2,3}$ Tujuan penelitian ini untuk mengetahui hubungan status bidan praktek swasta dengan pelayanan antenatal care di wilayah puskesmas Bumijawa Kabupaten Tegal tahun 2016.

\section{METODE PENELITIAN}

Rancangan penelitian yang digunakan dalam penelitian ini adalah observasi dengan pendekatan cross sectional. Variabel bebas dalam penelitian ini adalah status bidan praktek swasta dan variabel terikat dalam penelitian ini adalah pelayanan antenatal care.

Populasi dalam penelitian ini adalah bidan yang membuka praktik mandiri di wilayah Puskesmas Bumijawa sejumlah 24 bidan. Teknik pengambilan sampel dengan menggunakan metode total sample. Instrumen penelitian yang digunakan adalah lembar observasi dan kuesioner yang diisi oleh peneliti. Analisis univariat yaitu analisis yang digunakan terhadap tiap variabel dari hasil penelitian. Analisis bivariat ini menggunakan uji statistik chi-square

\section{HASIL PENELITIAN}

Karakteristik Bidan

Karakteristik bidan yang bekerja di wilayah Kecamatan Bumijawa Kabupaten Tegal bahwa ratarata umur responden 36,29 tahun, sebagian besar responden berpendidikan D-III $(91,7 \%)$, sebagian besar lama mengabdi responden 5-10 tahun $(54,2 \%)$.

\section{Status Bidan}

Tabel 1. Distribusi Frekuensi Status Bidan Praktek Swasta di Wilayah Kecamatan Bumijawa Kabupaten Tegal tahun 2016

\begin{tabular}{clcc}
\hline No. & Status bidan praktek mandiri & Frekuensi & Presentase (\%) \\
\hline 1. & BPS Delima & 10 & 41,7 \\
2. & BPS Bukan Delima & 14 & 58,3 \\
\hline \multicolumn{2}{c}{ Total } & 24 & 100 \\
\hline
\end{tabular}

Berdasarkan tabel 1 menunjukkan bahwa status bidan praktek swasta sebagian besar dengan status bidan praktek swasta bukan delima yaitu sebanyak14 responden $(58,3 \%)$.

\section{Pelayanan Antenatal Care}

Hasil penelitian tentang pelayanan Antenatal Care di wilayah kecamatan Bumijawa Kabupaten Tegal, seperti pada tabel 2 
Tabel 2. Distribusi Frekuensi Pelayanan Antenatal Care di Wilayah Kecamatan Bumijawa Kabupaten Tegal tahun 2016

\begin{tabular}{cccc}
\hline No. & Pelayanan Antenatal Care & Frekuensi & Presentase (\%) \\
\hline 1. & Sesuai standar & 15 & 62,5 \\
2. & Tidak sesuai standar & 9 & 37,5 \\
\hline \multicolumn{2}{r}{ Total } & 24 & 100 \\
\hline
\end{tabular}

Berdasarkan tabel 2 menunjukkan bahwa pelayanan Antenatal Care sebagian besar sesuai standar yaitu 15 responden $(62,5 \%)$.

\section{Hubungan antara Status Bidan Praktek Swasta dengan Pelayanan Antenatal Care}

Untuk mengetahui hubungan antara status bidan praktek swasta dengan pelayanan antenatal care di wilayah kecamatan Bumijawa Kabupaten Tegal tahun 2016, seperti pada tabel 3 berikut:

Tabel 3. Hubungan antara status bidan praktek swasta dengan pelayanan antenatal care di wilayah kecamatan Bumijawa Kabupaten Tegal tahun 2016

\begin{tabular}{|c|c|c|c|c|c|c|c|c|c|}
\hline \multirow{3}{*}{ No } & \multirow{3}{*}{$\begin{array}{c}\text { Status bidan } \\
\text { praktek Swasta }\end{array}$} & \multicolumn{4}{|c|}{ Pelayanan antenatal care } & \multicolumn{2}{|c|}{ Total } & \multirow{3}{*}{$\mathbf{X}^{2}$} & \multirow{3}{*}{$\begin{array}{c}P \\
\text { Value }\end{array}$} \\
\hline & & \multicolumn{2}{|c|}{$\begin{array}{l}\text { Sesuai } \\
\text { Standar }\end{array}$} & \multicolumn{2}{|c|}{$\begin{array}{c}\text { Tidak sesui } \\
\text { standar }\end{array}$} & \multirow[t]{2}{*}{$\Sigma$} & \multirow[t]{2}{*}{$\%$} & & \\
\hline & & $\Sigma$ & $\%$ & $\Sigma$ & $\%$ & & & & \\
\hline 1. & BPS Delima & 9 & 90,0 & 1 & 10,0 & 10 & 100 & 5,531 & 0,024 \\
\hline 2. & $\begin{array}{l}\text { BPS Bukan } \\
\text { Delima }\end{array}$ & 6 & 42,9 & 8 & 57,1 & 14 & 100 & & \\
\hline & Total & 15 & 62,5 & 9 & 37,5 & 24 & 100 & & \\
\hline
\end{tabular}

Tabel 3 menunjukkan bahwa status bidan BPS delima sebagian besar pelayanan antenatal care sesuai standar yaitu 9 responden (90\%), sedangkan status BPS Bukan Delima sebagian besar pelayanan antenatal care tidak sesuai standar yaitu 8 responden $(57,1 \%)$ dan dengan pelayanan ANC sesuai standar sejumlah 6 responden $(42,9 \%)$.

Hasil uji korelasi Chi Square diperoleh nilai $\mathrm{X}^{2}$ hitung 5,531 dan pvalue 0,024, berdasarkan level signifikan 0.05 dengan $\mathrm{df}=1$ maka nilai $\mathrm{X}^{2}$ tabel adalah 3,841 , hal ini menunjukkan bahwa $\mathrm{X}^{2}$ hitung lebih besar dari $\mathrm{X}^{2}$ tabel $(5,531>3,841)$ dan $p$ value lebih kecil dari $\alpha(0,024<0,05)$ yang berarti Ho ditolak dan Ha diterima artinya ada hubungan antara status bidan praktek Swasta dengan pelayanan antenatal care di wilayah Kecamatan Bumijawa Kabupaten Tegal tahun 2016.

\section{PEMBAHASAN}

\section{Status bidan praktek Swasta}

Hasil penelitian menunjukkan bahwa status bidan praktek swasta sebagian besar dengan status bidan praktek swasta bukan delima yaitu sebanyak 14 responden $(58,3 \%)$, dan status bidan praktek swasta delima ada 10 responden $(41,7 \%)$. Hal ini berarti bidan sebagai pelayanan kesehatan di wilayah kecamatan Bumijawa masih belum termasuk bidan Delima.

Bidan sebagai salah satu profesi dalam bidang kesehatan, memiliki kewenangan sesuai dengan Peraturan Menteri Kesehatan Republik Indonesia Nomor 1464/MENKES/PER/X/2010 tentang izin dan penyelenggaraan praktik bidan yaitu meliputi pelayanan kesehatan ibu, pelayanan kesehatan anak dan pelayanan kesehatan reproduksi perempuan dan keluarga berencana. $^{4}$

Menurut penelitian yang dilakukan Puspita, bahwa status bidan akan mempengaruhi kinerja dan pelayanan kesehatan bidan, bidan dengan status delima, akan termotivasi untuk mendorong memberikan pelayanan kesehatan secara profesional. ${ }^{5}$

Berdasarkan karakteristik bidan diketahui bahwa rata-rata umur responden adalah 36,29 tahun, merupakan umur dewasa,umur kemapanan dalam hal pengalaman menangani pasien. Hasil ini sesuai dengan penelitian yang dilakukan oleh Sihombing bahwa adanya hubungan antara umur 
responden dengan pelayanan kesehatan bidan karena diperoleh nilai $\mathrm{p}=0,003$. Hal ini dikarenakan semakin cukup umur seseorang akan lebih matang dalam berfikir dan bekerja. ${ }^{6}$

Umur mempengaruhi terhadap daya tangkap dan pola pikir seseorang. Semakin bertambah usia akan semakin berkembang pula daya tangkap dan pola pikirnya, sehingga pengetahuan yang diperolehnya semakin membaik. ${ }^{7}$ Pada usia dewasa, individu akan lebih berperan aktif dalam masyarakat dan kehidupan sosial serta lebih banyak melakukan persiapan demi suksesnya upaya menyesuaikan diri menuju usia tua, selain itu orang usia madya akan lebih banyak menggunakan banyak waktu untuk membaca. Kemampuan intelektual, pemecahan masalah, dan kemampuan verbal dilaporkan hampir tidak ada penurunan pada usia ini.

Status bidan delima (41,7\%), yaitu BPS sebagai bidan delima yang melalui proses pra kualifikasi dan validasi, hal ini untuk meningkatkan pelayanan yang berkualitas dengan cara melengkapi sarana dan prasarana serta memberikan pelayanan yang standar. Ikatan Bidan Indonesia (IBI) terus berpacu untuk menjadikan bidan semakin professional. Program bidan delima adalah sebuah program yang diciptakan untuk para Bidan Praktik Swasta (BPS) dalam rangka meningkatkan dan pembinaan kualitas pelayanan KB dan ${ }^{9}$ Kespro secara berkesinambungan. ${ }^{8}$

Berdasarkan tingkat pendidikan sebagian besar sudah lulus D-III kebidanan (91,7\%), artinya sudah banyak yang telah memenuhi ketentuan pemerintah, bahwa bidan harus menempuh pendidikan minimal D-III dan sebagain kecil responden berpendidikan D-IV.

Hasil penelitian ini sesuai dengan penelitian yang dilakukan oleh Ari Sukoco, ${ }^{9}$ yang telah dilakukan pada bidan di Bangsal Kebidanan Rumah Sakit Bhakti Wira Tamtama Semarang tahun 2008, didapatkan hasil bahwa ada beberapa faktor yang mempengaruhi kepuasana pelayanan kebidanan yaitu salah satunya pendidikan dimana sebagian besar adalah DIII Kebidanan. ${ }^{9}$

Status bidan didukung dari lama mengabdi responden di wilayah Puskesmas Bumijawa sebagian besar 5-10 tahun yaitu 13 responden (54,2\%). Hal ini berarti bahwa responden sudah lama menjadi bidan dan sudah banyak pengalaman yang didapatkan selama menjalankan tugas sebagai bidan di wilayah kerjanya. Bidan dengan lama bekerja 5-10 tahun akan mempunyai pengalaman bekerja yang lebih banyak dibandingkan dengan seseorang yang mempunyai lama bekerja > 5 tahun.

Semakin lama bekerja seseorang semakin banyak pengalaman yang di dapat dan semakin banyak kasus yang dihadapi, sehingga seseorang tersebut akan terampil dalam menyelesaikan pekerjaannya. ${ }^{10}$

\section{Pelayanan Antenatal Care}

Hasil penelitian menunjukkan bahwa pelayanan Antenatal Care sebagian besar sesuai standar yaitu 15 responden $(62,5 \%)$ sedangkan pelayanan Antenatal Care tidak sesuai standar yaitu sebanyak 9 responden $(37,5 \%)$.

Hasil penelitian ini sesuai dengan penelitian yang dilakukan oleh Widyawati ${ }^{11}$, bahwa kualitas pelayanan antenatal yang diberikan oleh bidan dalam kategori baik (80\%) ditandai dengan persentase ibu hamil di suatu wilayah, dalam kurun waktu tertentu, yang mendapatkan pelayanan antenatal sesuai standar paling sedikit empat kali, dengan tingginya cakupan K4 di Puskesmas diharapkan dapat menurunkan angka kematian ibu dan bayi. Dalam upaya pencapaian cakupan K4 tersebut diperlukan petugas/bidan, sarana dan pelayanan antenatal yang berkualitas. ${ }^{11}$

Pelayanan antenantal merupakan pelayanan yang diberikan terhadap ibu hamil oleh petugas kesehatan untuk memelihara kehamilannya yang dilakukan sesuai standar pelayanan antenantal yang ditetapkan dalam standar pelayanan kebidanan. Tujuan pelayanan antenantal adalah mengantarkan ibu hamil agar dapat bersalin dengan sehat dan memperoleh bayi yang sehat, mendeteksi dan mengantisipasi dini kelainan kehamilan dan deteksi serta antisipasi dini kelainan janin. $^{12}$

Pelayanan Antenatal Care sebagian besar sesuai standar (62,5\%), yaitu terutama tentang timbang berat badan (T1) (100\%), yang bertujuan mengukur berat badan dalam kilo gram tiap kali kunjungan. Kenaikan berat badan normal pada waktu hamil $0,5 \mathrm{~kg}$ per minggu mulai trimester kedua. Semua ibu hamil berpotensi mempunyai resiko. Resiko atau bahaya adalah terjadinya 
komplikasi dalam persalinan yang berdampak kepada $5 \mathrm{~K}$, yaitu kematian, kesakitan, kecacatan, ketidaknyamanan, dan ketidakpuasan pada bayi baru lahir. Untuk itu pemberian asuhan sejak kehamilan merupakan hal penting dalam membantu menurunkan AKI dimulai dari subsistem dan sistem yang ada di masyarakat yaitu keluarga. Dan khususnya bidan desa yang di masyarakat diharapkan dapat memberikan asuhan kebidanan yang berkualitas sesuai standar.

Pelayanan Antenatal Care tidak sesuai standar (37,5\%), artinya bidan dalam memberikan pelayanan ANC tidak memenuhi standar pelayanan ANC yang terkenal dengan $14 \mathrm{~T}$ yaitu paling banyak bidan tidak memberikan pelayanan ANC sesuai standar pada standar perawatan payudara, senam payudara dan pijat tekan payudara (T8) (74\%), hal ini dikarenakan pada perawatan payudara sebagian besar dilakukan pada saat menyusui. Prenatal breast care atau Perawatan payudara selama kehamilan anda adalah salah satu bagian penting yang harus anda perhatikan sebagai persiapan untuk menyusui nantinya. Saat kehamilan payudara akan membesar dan daerah sekitar puting akan lebih gelap warnanya dan juga lebih sensitive. Perawatan payudara saat hamil bertujuan untuk memelihara higiene payudara, melenturkan/ menguatkan puting susu dan mengeluarkan puting susu yang datar atau masuk kedalam (retracted nipple). ${ }^{13}$

Adapun pelayanan yang banyak tidak dilakukan saat ANC adalah pemeliharaan tingkat kebugaran/senam ibu hamil (T9) (75\%), hal ini dikarenakan senam hamil merupakan program baru di wilayah Puskesmas Bumijawa, juga karena ada mitos bahwa orang hamil tidak dibolehkan untuk melakukan banyak gerak termasuk senam hamil dan juga disebabkan dikarenakan kurangnya kesadaran ibu hamil mengenai pentingnya senam hamil, serta kurangnya informasi mengenai tahapan dari senam hamil.

Pelayanan ANC yang dilakukan berdasarkan indikasi, pada pelayanan pemeriksaan VDRL (T7), ibu hamil tidak dilakukan pemeriksaan, hal ini dikarenakan tidak adanya indikasi penyakit syifilis pada ibu hamil (0\%), sedangkan pada pemeriksaan urine dilakukan pemeriksaan pada 9 responden $(11 \%)$, hal ini dikarenakan ada indikasi kejadian pre-eklampis seperti ektremitas odema, pandangan kabur. Pemeriksaan reduksi urine atas indikasi (T12) hanya dilakukan pada 6 responden (7\%), didasarkan pada riwayat penyakit yang diderita ibu hamil yaitu penyakit Diabetes Mellitus.

Wilayah Kecamatan Bumijawa merupakan bukan wilayah yang terkena endemis gondok dan malaria sehingga pada pemberian terapi kapsul yodium untuk daerah endemis gondok (T13) dan pemberian terapi anti malaria untuk daerah endemis malaria (T14) tidak dilakukan (0\%).

\section{Hubungan antara status bidan praktek swasta dengan pelayanan antenatal care}

Hasil penelitian menunjukkan bahwa status bidan BPS Delima sebagian besar pelayanan antenatal care sesuai standar yaitu 9 responden (90\%), sedangkan status BPS Bukan Delima sebagian besar pelayanan antenatal care tidak sesuai standar yaitu 8 responden $(57,1 \%)$ dan dengan pelayanan ANC sesuai standar sejumlah 6 responden $(42,9 \%)$.

Hasil uji korelasi menunjukkan ada hubungan antara status bidan praktek swasta dengan pelayanan antenatal care di wilayah puskesmas Bumijawa Kabupaten Tegal ( $p$ value 0,024), hal ini berarti bahwa bidan dengan status bidan delima lebih profesional dalam pelayanan ANC dibandingkan dengan bidan praktek swasta yang bukan delima, dengan menjadi bidan delima secara tidak langsung fasilitas pelayanan akan tersedia, sehingga akan meningkatkan mutu pelayanan.

Sesuai kebijakan program pelayanan asuhan antenatal harus sesuai standar yaitu "14 $T$ ", meliputi: ${ }^{14}$

1. Timbang berat badan (T1)

2. Ukur berat badan dalam kilo gram tiap kali kunjungan. Kenaikan berat badan normal pada waktu hamil $0,5 \mathrm{~kg}$ per minggu mulai trimester kedua.

3. Ukur tekanan darah (T2)

4. Tekanan darah yang normal 110/80 - 140/90 mmHg, bila melebihi dari 140/90 mmHg perlu diwaspadai adanya preeklamsi.

5. Ukur tinggi fundus uteri (T3)

6. Pemberian tablet Fe sebanyak 90 tablet selama kehamilan (T4)

7. Pemberian imunisasi TT (T5) 
8. Pemeriksaan $\mathrm{Hb}$ (T6)

9. Pemeriksaan VDRL (T7)

10. Perawatan payudara, senam payudara dan pijat tekan payudara (T8)

11. Pemeliharaan tingkat kebugaran/senam ibu hamil (T9)

12. Temu wicara dalam rangka persiapan rujukan (T10)

13. Pemeriksaan protein urine atas indikasi (T11)

14. Pemeriksaan reduksi urine atas indikasi (T12)

15. Pemberian terapi kapsul yodium untuk daerah endemis gondok (T13)

16. Pemberian terapi anti malaria untuk daerah endemis malaria (T14)

Salah satu faktor dari pelaksanaan ANC adalah kualitas pelayanan, karena secara langsung dapat mempengaruhi pelayanan oleh wanita dengan penyediaan pelayanan melalui pemberian dan penerimaan informasi. Penghargaan terhadap klien dalam pemberiaan pelayanan yang yang kompeten dengan didukung infrstruktur yang memadai. ${ }^{5}$

Hal ini sesuai dengan penelitian yang dilakukan oleh Shofiyyah, dengan judul hubungan antara kualitas pelayanan dengan pelaksanaan ANC di kabupaten Gresik, didapatkan hasil bahwa ada hubungan yang signifikan antara antara kualitas pelayanan dengan pelaksanaan ANC di kabupaten Gresik ( $p$ value $=0,000<0,05$ ), semakin baik kualitas pelayanan tenaga kesehatan maka semakin baik cakupan ANC. ${ }^{15}$

Menurut hasil penelitian bahwa bidan yang bukan delima ada yang melakukan pelayanan ANC yang baik yaitu 23 responden $(74,2 \%)$, hal ini disebabkan karena sudah menjadi kewajiban bagi tenaga kesehatan untuk menambah dan memperbaharui informasi pelayanan ANC dan melakukan pelayanan dengan sebaik-baiknya, serta mematuhi peraturan yang telah ditetapkan oleh dinas kesehatan.

\section{SIMPULAN}

Berdasarkan hasil penelitian yang telah dilakukan, maka dapat ditarik simpulan sebagai berikut:

1. Status bidan praktek swasta sebagian besar dengan status bidan praktek swasta bukan delima $(58,3 \%)$

2. Pelayanan Antenatal Care sebagian besar sesuai standar (58,3\%)

3. Ada hubungan yang signifikan antara status bidan praktek swasta dengan pelayanan antenatal care di wilayah kecamatan Bumijawa Kabupaten Tegal tahun 2016 ( $p$ value=0,024).

\section{SARAN}

\section{Peneliti}

Diharapkan dapat mengembangkan penelitian ini, dengan menambahan variabel bebas yang dapat mempengaruhi pelayanan antenatal care seperti pendidikan dan pelatihan pelayanan antenatal care, supervisi bidan koordinator dan lain-lain.

2. Bidan

Diharapkan bidan praktek swasta yang belum delima agar dapat mengikuti program bidan delima, sehingga dalam melakukan pelayanan ANC sesuai dengan standar pelayanan, serta dengan memasang famplet acuan pelayanan ANC sesuai dengan petunjuk dari Departemen Kesehatan.

3. Dinas Kesehatan

Mewajibkan pada bidan untuk meningkatkan pelayanan ANC sesuai standar $17 \mathrm{~T}$ dengan cara mengikuti pelatihan-pelatihan dan seminar yang berhubungan dengan ANC.

\section{DAFTAR PUSTAKA}

1. Ikatan Bidan Indonesia. Buku Instrumen Bidan Delima 1. Jakarta: USAID; 2005.

2. Pakage. Hubungan Kinerja Bidan Dalam Pelayanan Anc (Antenatal Care) Dengan Kunjungan K-4 pada Ibu Hamil di Kabupaten Nabire, Papua Tahun 2014; 2014.

3. Mufdilah. Catatan Konsep Kebidanan Plus Materi Bidan Delima. Yogyakarta: Mitra Cendikia;. 2009 
4. Peraturan Menteri Kesehatan Republik Indonesia Nomor 1464/MENKES/PER/X/2010 tentang izin praktek bidan

5. Puspita. Pengaruh Status Bidan terhadap Pelayanan Kesehatan. Jakarta: Rineka Cipta; 2009

6. Sihombing. Hubungan Karakteristik dengan Perilaku Bidan dalam Memberikan Pelayanan Kesehatan Ibu di Wilayah Kerja Dinas Kesehatan Gunungsitoli Kabupaten Nias Tahun 2003. Skripsi. Fakultas Ilmu Kesehatan Masyarakat USU Medan; 2004

7. Notoadmodjo, S, Metode Penelitian Kesehatan, Jakarta: Rineka Cipta; 2010

8. Hidayat, AAA. Riset Keperawatan dan Teknik Penulisan Ilmiah. Jakarta: Penerbit Salemba; 2007.

9. Ari Sukoco. Faktor-faktor yang Mempengaruhi Kepuasan Pelayanan Kebidanan pada Bidan di Bangsal Kebidanan Rumah Sakit Bhakti Wira Tamtama Semarang tahun 2008. Skripsi. Unimus; 2008

10. Mangkuprawira. Manajemen Sumber Daya Manusia Strategik. Jakarta: Ghalia Indonesia; 2004

11. Widyastuti. Asuhan Kebidanan pada Kehamilan Fisiologis. Jakarta: Salemba Medika; 2001

12. Depkes RI, Profil Kesehatan Indonesia tahun 2012. Jakarta: Depkes RI; 2013.

13. Bandiyah. Kehamilan, Persalinan dan Gangguan Kehamilan. Yogyakarta: Nuha Medika; 2009

14. Depkes RI. Standar Mutu Pelayanan Bidan. Depkes RI; 2012

15. Shofiyyah. Hubungan antara Kualitas Pelayanan dengan Pelaksanaan ANC di Kabupaten Gresik tahun 2009. Skripsi; 2009. 